\title{
Regulatory harmonization in the illumination of sport facilities: a challenge for energy savings and users well-being
}

\author{
R. Amorim ${ }^{1}$, V. Molina ${ }^{2}$ and A. Peña-García ${ }^{1}$ \\ ${ }^{1}$ Department of Civil Engineering \\ ${ }^{2}$ Department of Management \\ E.T.S.I. Caminos, Canales y Puertos., University of Granada \\ Campus Fuentenueva s/n, 18074 Granada (Spain) \\ Phone/Fax number:+0034 958249 435, e-mail: pgarcia@ugr.es
}

\begin{abstract}
This study is a comparative analysis of the main differences in the lighting requirements of sports facilities in different regulatory frameworks. The target is to identify regulatory differences and common points in potential impact on financial profitability, visual comfort, people safety and environmental impact. It is also pretended to identify critical parameters that may help to avoid serious problems such as violence among spectators. The integral management of these facilities requires important considerations on new technologies to provide good lighting for users (athletes and spectators), savings in the very high energy consumption and control the impact of lighting on some psychological and physiological aspects of users directly related to violence. In the European standard for sports lighting EN 12193:2007, for example, we see a great concern about the sustainability of installations. The update of the Brazilian standard NBR 8837 is also expected to give an important role to sustainability and quality of artificial lighting to provide services in the sports areas. However, remarkable differences among both regulatory frameworks still remain. Thus regulatory harmonization in the lighting of sports facilities can be beneficial for both, sustainable management and profitable use of these installations.
\end{abstract}

\section{Key words}

Energy savings, Sustainability, Ergonomics, Sport installations.

\section{Introduction}

The new lighting technologies are increasing the performance of visual tasks at very competitive cost and reasonable environmental impact. Depending on the purpose, there are different types of light sources that can be used in different parts of one given installation. Hence, the predominance of discharge lamps in all types of lighting is decreasing in the last decades due to the quick expansion of the Light Emitting Diode, universally known as LED.
The evolution of LED light sources has been spectacular since the patent of Holonyak in the sixties. However, except for some visual application such as remote control devices, computers application and some kinds os signaling, the use of LED lamps to $100 \%$ illuminate streets and facilities is relatively new.

The study of Veitch [1] established that the lighting quality is the result of a set of components, being them: the local architecture, human performance (visual comfort, visual performance) and consumption (financian impact and energy). Thus, we see that new lighting technologies such as in sports facilities must go beyond good levels of lighting and also be economically sustainable.

\subsection{New lighting technologies: higher energy savings and lower environmental impact}

Some of the main energy efficiency measures were settled as a consequence of the fuel crisis some decades ago. Thus, some initiatives are promoting forms of rational and efficient use of energy as well as tax incentives and advantages on the purchase of more efficient equipment. Therefore, energy efficiency responds to actions taken in the supply and demand without sacrificing the well-being, thereby improving the quality and reduce energy consumption generating savings for the population. Some of these measures also reduce the emission of greenhouse gases [2].

We know that the lamps not only differ from each other by their different luminous flux, but also for its power, energy consumed and physical properties of the light emitted. This means that reducing consumption without reducing the amount of light increases energy efficiency, as shown in table 1. 
Table I. - Equivalence replacement lamps in a home.

\begin{tabular}{|c|c|c|}
\hline Before & After & Energy Saving \% \\
\hline $\begin{array}{c}\text { Incandescent } \\
\text { lamp }\end{array}$ & $\begin{array}{c}\text { Energy saving lamps } \\
\text { with the same light } \\
\text { intensity }\end{array}$ & percentage savings \\
\hline $40 \mathrm{~W}$ & $9 \mathrm{~W}$ & 82 \\
\hline $60 \mathrm{~W}$ & $11 \mathrm{~W}$ & 82 \\
\hline $75 \mathrm{~W}$ & $15 \mathrm{~W}$ & 80 \\
\hline $100 \mathrm{~W}$ & $20 \mathrm{~W}$ & 80 \\
\hline
\end{tabular}

(Source: Endesa)

It leads to another extremely important topic of maximum actuality: sustainability. Due to an increase in the production of toxic gases that destroy the ozone layer, climate change is becoming increasingly drastic and dangerous. The concept of sustainability emerged in the 80s [3]. The Brundtland commission understands that sustainable development can be understood as a means to meet current necessities without compromising the ability of future generations to meet their necessities. Thus, the concept of sustainability it is a combination of environmental integrity, social equality and economic prosperity.

In parallel, it was recognized that building is one of the main causes of the degradation of environmental resources, enhancing the ability to develop in a sustainable way with the renewal of the same [4]. In the plans of renewable energy measures should be included strategies for the integration of renewable energy systems influencing means of savings and energy efficiency.

1.2. Non-visual effects of light related to the psychophysiological characteristics of the sports practitioner: regulation of sports lighting

Besides its lower consumption, LED technology is interesting for our purposes due to the remarkable impact on the non-visual paths. It means that LED illumination can influence effects like arousal, emotions, relaxation, stress and, of course, disposal to violence. It is known that the users of streets whose public lighting is more intense or has specific color characteristics feel safer or more vulnerable [5-8]. Although it is not $100 \%$ clear how light influences such feelings, it seems obvious that some hormones secreted by the human body (melatonin and cortisol) through the exposure to certain light types, are the key in these processes.

Hence, one of the most important cycles of the human body related to the light is the melatonin cycle. This neurohormone is secreted by the pineal gland reducing arousal and causing the body to relax where on the contrary, the inhibition of this neurohormone leads to increased levels of alert and attention. On the other hand cortisol, a hormone whose cycle also responds to light levels, plays a role in the reverse mode of melatonin where its presence helps to maintain alert levels necessary for everyday life.

With the advances in recent years we see that sports facilities are becoming more optimal and then designers are increasingly concerned about saving and give a better sense of comfort to the athletes and spectators. In some facilities, different colors and light intensities are used in each circumstance to achieve the objective proposed for this area such as a softer lighting in the center light of different hues in the logos of sponsors, stronger and more intense color in the staging area and light mildest in the area of press conference. Making in each of the areas the people who are their feel different sensations in order to achieve the proposed objectives [11].

Concerning the feelings of the users, violence among spectators is a major topic that worries Governments, Institutions and also the own users of sport facilities. Given the high impact of accurate lighting on human emotions, we consider that the correct actions on the lighting installations may lead to a remarkable decrease in violence parallel to the necessary energy savings.

Thus, we will focus this work as a proposal to harmonize the standards in sport lighting together with some actions to provide accurate lighting that can help to decrease aggressive behaviors.

\section{Materials and Methods}

In this work we will depart from a comparative analysis of the European and Brazilian patterns of lighting in sports facilities [12]. Regulatory differences and commonalities with potential impact on the facilities in the financial, environmental and sports performance will be highlighted and discussed in order to propose work and matching lines.

We see that the main concern of European standards is on sustainability and energy efficiency that will be recommended to be adopted by the Brazilian committee currently working on updating the standard in this country. Differences in some critical quantitative parameters of lighting, such as uniformity, will also be highlighted in order to improve the performance of facilities for users, especially for those with some special needs that may suffer some risk of exclusion.

A. Standards 
According to the European Standard EN 12193: 2007 [9] on lighting do the most popular sports in Europe, it is important to consider the kind of lighting in the sports facility and observe the viewing distance of the viewer. The higher the level of practice of play and the greater the viewing distance of the viewer, the greater should be the kind of selected lighting. Already in the Brazilian standard NBR sports lighting 8837 [10], it is set only minimum levels of illuminance and uniformities in local sports. In both cases, it is observed that the visual welfare of both the spectator as the athlete / athlete is paramount in the rules. Where is obtained through appropriate factors for each activity illuminance, and the existence of an area without obscurations by light.

\section{Proposal}

We know that too much light can disturb the players and too little can hinder the view of the spectators, and clear visibility helps players to perform at their best glare which also works with the video cameras capture the action of a better way and viewers can better see the game. As seen in the high levels of lighting with white LEDs that promote concentration and attention and moderate levels with warm halogen or fluorescent lamps promote relaxation. If we add the recent discoveries that indicate new and more complex interactions between light and limbic system (emotions, aggressiveness, etc.), the resulting scenario to take advantage of all non-visual effects of light is even more complex.

Considering the tables II and III we see a significant gap between the recommended uniformities and illuminances in Brazil and Europe. Given the importance of these parameters and its impact on the performance of the game itself and even potential health problems such as headaches, stress and others, we recommend increasing the uniformity levels requested in the future Brazilian rules on sports lighting.

Table II - Illuminance and their uniformity (adapted from Brazilian Standard [10] and [11]).

\begin{tabular}{|c|c|c|c|c|c|}
\hline Sport & recreation & Unif. & competition & professional & Unif. \\
\hline $\begin{array}{c}\text { American } \\
\text { football }\end{array}$ & 100 & $1: 3$ & 300 & - & $1: 1,5$ \\
\hline $\begin{array}{c}\text { Indoor } \\
\text { soccer } \\
\text { (outside) }\end{array}$ & 100 & $1: 3$ & 200 & 300 & $1: 1,5$ \\
\hline $\begin{array}{c}\text { Fitness } \\
\text { (outside) }\end{array}$ & 100 & $1: 3$ & 200 & 300 & $1: 1,5$ \\
\hline Handball & 100 & $1: 3$ & 300 & - & $1: 1,5$ \\
\hline $\begin{array}{c}\text { Equestria } \\
\text { nism }\end{array}$ & 50 & $1: 3$ & 100 & 200 & $1: 1,5$ \\
\hline $\begin{array}{c}\text { Roller } \\
\text { hockey }\end{array}$ & 200 & $1: 3$ & 300 & 500 & $1: 1,5$ \\
\hline $\begin{array}{c}\text { Grass } \\
\text { hockey }\end{array}$ & 100 & $1: 3$ & 200 & 300 & $1: 1,5$ \\
\hline
\end{tabular}

Table III - Illuminance level in Spain (adapted from European standard [9] and [11]).

\begin{tabular}{|l|c|c|c|c|c|}
\hline \multicolumn{1}{|c|}{ Sport } & recreation & training & Unif. & competition & Unif. \\
\hline $\begin{array}{l}\text { Indoor } \\
\text { football }\end{array}$ & $50(150)$ & $60(150)$ & $1: 3$ & $>600$ & $2: 3$ \\
\hline volleyball & 60 & 100 & $1: 3$ & $300-600$ & $2: 3$ \\
\hline basketball & 60 & 100 & $1: 3$ & $300-600$ & $2: 3$ \\
\hline tenris & 150 & 250 & $1: 2$ & $400-700$ & $2: 3$ \\
\hline baseball & 150 & 250 & $1: 2$ & $400-700$ & $2: 3$ \\
\hline
\end{tabular}

The differences in the luminal parameters, especially in competition, make recommendable to go to the higher levels for athletes and lower to moderate for spectators. This can be achieved only with LED, that can be dimmed and orientated depending on the needs of all kind of users.

Hence, besides the use of LED light sources to get adapted to the correct development of the activity, here it is proposed to use such light sources to influence the nonvisual paths in the spectators and control emotions and, hence, violence.

The results will not only improve safety and well-being, but also the profitability and sustainability of sports facilities and the cities hosting them.

\section{Conclusion}

Important gaps between the Brazilian and European regulations on sports lighting were detected and, given the importance of the lighting needs of these groups at risk of exclusion, a complete revision of the Brazilian standard and its possible harmonization with the European in the field of sports lighting uniformity it is proposed in this article. This is because sport is considered a powerful tool for integration and cannot in any way be risky for inadequate lighting installations. In this way we will improve not only the means of inclusion through sport but also competitions at world levels such as Olympic Games and more specifically in sports competitions involving people at risk of exclusion such as the Paralympic Games can be improved

Another point also considered in this work is that the use of LED lamps diminish the energetic consumption of an installation can have a remarkable impact on sustainability and non-visual effects of light like violence among spectators, mainly if the LED follow certain patterns of emission. So we conclude that it is necessary to make a harmonization in standards on sport illumination and adapt them to the new light sources because most are out of date 
or not accompanied the evolution of new light sources.

In summary, the management of sports facilities should be considered from a global perspective, which goes beyond energy efficiency and financial profitability, the actions to be taken should include sports performance in competition and training, welfare of athletes and spectators, and last but not least, the real intention of reducing violence in and outside the premises.

\section{Future Research}

Besides deeper studies on the harmonization of other regulations on lighting of sport facilities, further research need to be made from these extremely important issues for today's society, with decreasing order of violence among spectators, which is a major problem in many countries and helping the sport to become a tool to integration of groups at risk of exclusion. In addition we must take into account the known effects of light on human psychology and health, and carry out study for the sports facilities to have a lighting that can provide these improvements.

\section{Acknowledgement}

This research was partially implemented with financial support provided by CAPES, Higher Education Personnel Improvement Coordination - Brazil, through the Doctoral scholarship (BEX 0947 / 14-8).

\section{References}

[1] Veitch, J. A. (2000). Lighting guidelines from lighting quality research. CIBSE National Conference, 2000.

[2]Poveda, M. (2007). Eficiencia energética: recurso no aprovechado. OLADE. Quito.

[3] Brundtland, G. H. (1985). World commission on environment and development. Environmental policy and law, 14(1), 26-30

[4] Lamberts,R.,Dutra,L.,Pereira, F.O.R.(2004).Eficiência energética na arquitetura. 2. ed. São Paulo: Prolivros.
[5] Peña-García,A. Hurtado, A. Aguilar-Luzón, M.C.(2015) "Impact of public lighting on pedestrians' perception of safety and well-being," Safety Science, 78, 142-148.

[6] Peña-García,A. Hurtado, A. Aguilar-Luzón, M.C. (2016) "Considerations about the impact of public lighting on pedestrians' perception of safety and well-being," Safety Science, 89, 315-318.

[7] Hurtado González, A., Peña-García, A., Rabaza, O., Espín Estrella, A., Aguilar Luzón, MC. (2013) “Impacto psicológico del alumbrado público sobre los peatones y correlación con la iluminancia media y la uniformidad”. XXXIX Simposium Nacional de Alumbrado. Mataró (Barcelona), 22-25 de mayo. ISBN: 978-84-695-7309-9.

[8] Hurtado González, A., Espín Estrella, A., Aguilar Luzón, M.C., Peña-García, A. (2014) "Impacto psicológico del alumbrado público sobre los peatones y correlación con los parámetros luminotécnicos. Parte II, Resultados”. XL Simposium Nacional de Alumbrado. Málaga, 28-31 de mayo. ISBN: 978-84695-9937-2.

[9] EN 12193:2007, "Light and Lighting", 25 October,2007, Policy and Strategy Committee.

[10] NBR8837, Associação Brasileira de Nomas Técnicas ABNT, Sport Lighting Specification, Abril 1985.

[11] Amorim, R., Molina-Moreno, V., Peña-García, A. (2016). Proposal for Sustainable Dynamic Lighting in Sport Facilities to Decrease Violence among Spectators. Sustainability 8, 1298 (10 pp).

[12] Amorim, R.R., Molina, V., Peña-García, A.(2016) "Proposal on Brazilian-European regulatory harmonization for optimal performance of lighting installations in sport facilities. Potential implications on sport as a tool for inclusion / Proposta sobre a harmonização da regulamentação brasileira - européia para o desempenho ideal de equipamento de iluminação em in stalações desportivas. Potenciais implicações no esporte como ferramenta de inclusão”. XVI Congresso de Ciências do Desporto e Educação Física dos Países de Língua Portuguesa. Oporto (Portugal), 27-30 de septiembre. 